\title{
New Development of Chinese Literary Anthropology*
}

\author{
HU Jian-sheng \\ Shanghai Jiao Tong University, Shanghai, China
}

\begin{abstract}
Chinese literary anthropology, growing out of comparative literature and cross-cultural studies at the end of the 20th century, is a notably innovative research paradigm in contemporary Chinese humanities and enters a new stage at the beginning of the 21st century. Firstly, this essay attempts to interpret how Chinese literary anthropology responds accordingly to the new development of international anthropology and mythology, updates the postmodern concept of myth and the pattern of the mythological knowledge, thereby constructing the core knowledge of Confucian myth in modern Chinese context. Afterward, it discusses the differences between the great tradition and the little tradition, and the significance of returning to the sacred context. Last, the focus of archetypal criticism in the context of Chinese anthropology has moved from literary concerns to cultural concerns and employing the quadruple evidences and five kinds of narratives to comprehensively interpret Confucian classics.
\end{abstract}

Keywords: Chinese literary anthropology, Ye Shuxian, post-modern concept of myth, great tradition, cultural archetype, research on Confucian mythology

\section{Introduction}

In China, Chinese literary anthropology, growing out of comparative literature and cross-cultural studies at the end of the 20th century, is a notably innovative research paradigm and enters a new stage at the beginning of the new century. Ye Shuxian, one of the famous scholars in cross-cultural studies and comparative literature, is the main initiator of Chinese literary anthropology. In recent years, he has published a lot on the topic, such as Series of Mythistory, Books of Mythology and Exploring the Mythological Origin of Chinese Civilization, which have declared a new paradigmatic shift of Chinese humanities. This anthropological turn can be seen as the second revolution of Chinese literary anthropology, from the scientific paradigm of humanities to the interpretation of culture. The most significant achievement is Series of Mythistory. This essay endeavors to construct the local core knowledge from three aspects - the post-modern concept of myth, the return to the great tradition of the sacred context and the mythical archetype of cultural text-after elaborating how Chinese literary anthropology responds accordingly to the new development of international anthropology and mythology, and reconceptualizing the mythical concepts and the pattern of the mythological knowledge.

\footnotetext{
* Acknowledgements: This paper is sponsored by: (1) Special Fund Project of Interdisciplinary Research between Arts and Science of Shanghai Jiao Tong University, China: the phased objectives of "Social Space and the Cultural Representation of Confucian in Pre-Qin Age" (13JCY12); (2) China National Find of Social Sciences "The Theory and Method of Literary Anthropology”.

HU Jian-sheng, PhD., Associate Professor at School of Humanities, Shanghai Jiao Tong University, China. His research field covers Chinese Literary Anthropology, Cross-culture research, Chinese classical culture and literature.
} 


\section{Post-modern Concept of Myth}

Since scholars such as Liang Qichao 梁启超 (1873-1929) and Jiang Guanyun 蒋观云 (1866-1929) introduced the mythical concept to Chinese academia in 1903, there have been literature research of Chinese mythology represented by Zhou Zuoren 周作人 (1885-1967), Mao Dun 茅盾 (1896-1981), Xie Liuyi 谢六 逸 (1898-1945), etc. and historical research of myth and legend represented by Gu Jiegang 顾颉刚 (1893-1980), Yang Kuan 杨宽 (1914-2005), etc. The former focuses on constrcting the myth from the classical Chinese texts, and the latter is concerned with restoring the mythical and legendary features of ancient history by making use of myth. The mythical concept has been neglected in Chinese literature for more than one hundred years, and been taken to be "fictional, fantasy, unreal, irrational, literary". When Ye Shuxian discussed his early mythological research at the end of the 20th century, he described: "I literarily studied myth, and attempted to break down the disciplinary boundaries among philosophy, epistemology and literature."”

At the beginning of the 21st century, Ye Shuxian started to jump out of the boundary of the literary concept of myth, and investigated the local concept of myth in the light of the international mythological development. He wrote a series of essays on the post-modern concept of myth such as "Post-modern Mythical Concept”, "Discuss New Mythicism Again”, "Comparative Mythology Perspective of Exploring Origin of Chinese Civilization”, "Meeting the Paradigm Shift of Mythology”, and translated essays such as "The Sacred Occurrence of Narrative-Rectification of the Name of Myth.” He insists that we can never discuss history and thought unless we understand myth. He also thought that Chinese academia should awaken from the self-enclosed concept of myth, so that myth could be released from the confinement of written text. He writes in Meeting the Paradigmatic Shift of Mythology: "I hope that myth can be liberated from the sphere of literary concept, and be used as the cultural gene, so that it will be the effective tool of breaking down the disciplinary boundaries among literature, history, philosophy, religion and psychology."2 His preface "Myth: Archetypal Code of Chinese Culture" to Series of Mythistory accurately summarizes the concept of new-mythicism in the 21st century. He argues: "the past experience has shown, when we break the literary limitations in Chinese mythology, the new mythical concept will play an important role in the inter-disciplinary knowledge integration, and guide humanists to keep open-minded, to seek the cross-discipline way, to discover and solve the new problems.”3 and "Myth will be the common source of literature, history, philosophy, art, religion, psychology, politic, education, law, etc. so the various disciplines which we classify, all related to myth, especially, if we trace the primal stage of these subjects, inevitably, we will be come into the common field of mythic narrative.”4 He has not taken myth as a literary concept, but as a tool which can effectively integrate the advantages of multi-disciplinary to study Chinese traditional culture. Likewise, he also argues that myth as a cultural gene can help us to understand the basic structure and coding function to the cosmologies, values,

\footnotetext{
${ }^{1}$ Ye Shuxian, Meeting the Paradigm Shift of Mythology, Ethnic Arts Quarterly, 3 (2009), 20. About Ye Shuxian's early mythic concept, see his mythological masterpiece: Chinese mythological philosophy (China Social Science Press, 1992). There are three parts including eight chapters: The titles of the three parts are "Meta-language of Myth", “Temporal and Spatial Philosophy of Myth" and "Bio-philosophy of Myth". He uses the theory as structuralism, anthropology and archetypal critical to study Chinese traditional myth, which undoubtedly taking many new methods to Chinese modern academia. But due to the limitation of the thoughts, his mythical concept basically belongs to the scientific paradigm of anthropology.

${ }^{2}$ Ye Shuxian, Meeting the Paradigm Shift of Mythology, Ethnic Arts Quarterly, 3 (2009), 20.

${ }^{3}$ Ye Shuxian, "Myth: Archetype Code of Chinese Culture”, in Tang Qicui, Ritual Institutional Civilization and Mythical Code, (Guangzhou: Nanfang Daily Press, 2011), 2. This book is one of Series of Mythistory which makes use of new mythical concept to interpret the mythological thinking and cultural genes in Confucian classic Liji 礼记.

${ }^{4}$ Ye Shuxian, Meeting the Paradigm Shift of Mythology, Ethnic Arts Quarterly, 3 (2009), 22.
} 
rituals of a given culture. Therefore, only if myth is liberated from the ruptured discipline and restored to its property of cultural gene, can we really access Chinese culture and avoid serious sheltering and misreading by the disciplinary separation.

Since the middle of the 20th century, Ye Shuxian's reinvention and transformation of mythical concept have certainly benefited from the rapid development of international mythology, anthropology and post-modern thinking. As regards the post-modern concept of knowledge, he was influenced by French philosophy of the post-modernists such as Michel Foucault and Jacques Derrida. He also repeatedly recommended Lyotard's Postmodern Condition to Chinese readers. In comparative religion, comparative mythology and anthropology, he accepted the symbolic and mythological theories of Mircea Eliade, Ernst Cassirer, Roland Barthes and Claude Levi-Strauss, Geoges Dumezil, Clifford Geertz, etc. He often introduced the six volumes of Myth Theory edited by the international mythologist Robert Siegel to Chinese academia, in order to inspire domestic scholars who have pure literary concept of myth, to keep up with the mythological development in the postmodern era. In archaeomythology, he directly takes inspiration from exploring the origin of the Western civilization and biological research as German anthropologist Walter Burkert, and the archaeomythological research paradigm of the famous American prehistoric archaeomythologist Marija Gimbutas, and British comparative mythologist Charles Penglase, etc. ${ }^{5}$ Of course, the direct influence on his reflection about modern Chinese concept of myth is A Short History of Myth written by British comparative religious scientist Karen Armstrong. He clearly summarizes and evaluates her concept of myth in his essay "Post-modern Mythic Concept": "Originally, the author wants to express neither the mythic narrative like the history of literature which we have already been familiar with or even tired of, nor the entire evolutional history of mythical stories, but the concept of myth focusing on sacred context. In short, it is a short history of myth not from the literary perspective, but from the thinking perspective, which is the declaration of invoking mythic thought and human spirit to reproduce, and a comprehensive pattern of post-modern concept of myth." ${ }^{6}$ He clearly realizes that Armstrong focuses on the interactive relationship between myth and ritual activities. Especially, as regards ancient Chinese myth in the Axis Period, she argues that the archaic peoples pay more attention to the ceremony than to the writing. Based on her viewpoints, he points out that post-modern concept of myth has offered a fresh angle to reinterpreting Confucian myth.

Inspired by the post-modern concept of myth, Ye Shuxian insightfully discovers that the key to interpreting Confucian myth is the keyword "holy" 圣. From this point of departure, he is no longer confined in his research only to the non-mainstream ideological texts such as Laozi 老子, Zhuangzi 庄子, Shanhaijing 山海经, Chuci 楚辞, and Huananzi 淮南子. He finds out how to access the mainstream ideology of Chinese culture-Confucianism, and he cracks the literary presentation of Confucius so-called "the Master never talked of prodigies, feats of strength, disorders of spirits or spirits” 子不语怪、力、乱, and opens up a large door to the local core culture for mythology in the new century. He says: "the characteristic of local religion and myth, as

\footnotetext{
${ }^{5}$ For more information, mainly see Foucault, The Order of Things; and Derrida, Writing and Difference; and Eliade, The Sacred and the Profane, The Myth of the Eternal Return, Shamanism: Archaic Techniques of Ecstasy; and Cassirer, An Essay on Men, Philosophy of Symbolic Form; Levi-Strauss, the Savage Mind, Mythology; Geertz, The Interpretation of Cultures. He has translated Gimbutas' The Living Goddesses. And Charles Penglase puts forward the similar mythic concept when he investigates the oriental characteristics of Greek mythological thought. See Charles Penglase, Greek Myths and Mesopotamia (London: Routledge, 1994). Also see Wang Qian, The Brief History of Greek Mythological Research in 20th Century (Xi'an: Shanxi Normal University Press, 2011), 94.

${ }^{6}$ Ye Shuxian, Post-modern Concept of Myth, Chinese Comparative Literature, 1 (2007), 53.
} 
the keywords indicates, is not the 'gods', but the 'holy'... Combination of gods and holy is the basic subject of comparative religion and mythology...Confucian construction of saint worship is not only the biggest myth in China, but also the most far-reaching myth."7 The new concept of myth avoids the one-sided commentary of mythological research in Chinese cultural context. It also deals with the differences between Chinese and Western myths to show that the former stresses the saint worship of the individual or the collective while the latter remains detached from the man's world, namely, the great man who has the sacred characters of saints. At the same time, he puts forward the six essential aspects when exploring the origin of Confucian thought system and discourse pattern.

A. Confucian mythical image system represented by feng 凤, lin 麟, jade ware and other sacred objects;

B. Confucian mythistorical concept of the genealogy of the sacred king based on the saint worship such as “Yao 尧, Shun 舜, Yu 禹, Tang 汤, Wen 文, Wu 武”, etc.

C. Confucian mythical philosophical keywords focusing on destiny 命, virtue 德, mind 心, ren 仁, yi 义, etc.

D. Confucian mythical ritual and sacred space focusing on ritual and music, Confucian temple and ceremony of offering sacrifices.

E. Mythical code of compiling literary structure, procedural words and phrases, ceremonial oath and alliance of Confucian classic.

F. The mythical context of the Confucianism during the early period. ${ }^{8}$

This new mythic concept, based on the above six aspects of sacred objects, saints, the holy way, ritual and music, sacred books, sacred context, etc. will be quite thought-provoking for Confucian studies.

In short, the Confucian mythic concept demonstrates the paradigmatic turn of Chinese literary anthropology in recent years. If we apply the new mythic concept to Confucian myth, it will lend cross-cultural vitality to Confucian tradition, and we can really perceive the archetypal function of myth as cultural genes.

\section{Return to the Sacred Context of the Great Tradition}

Through his interpretation of Chinese classics and prehistoric culture, Ye Shuxian discovered the great tradition in local culture. The concepts of the great tradition and the little tradition are borrowed from Western cultural anthropology, put forward by the American anthropologist Robert Redfield in Peasant Society and Culture: an Anthropological Approach to Civilization in 1956. In his book, the great tradition is referred as the state and power, which is the written culture controlled by the educated class while the little tradition is viewed as the countryside, which is the popular culture that the peasants inherit along with the oral pattern. ${ }^{9}$ But he doesn't rigidly adhere to the definition of the anthropologist. According to specific reality of local knowledge, he carries out a change of the great tradition and the little tradition that their meanings are entirely opposite to their original meanings. He says in The Great Tradition and the Little Tradition of Chinese Culture: "Accordance with the classification of semiotics to re-examine the cultural tradition, we view the tradition of

\footnotetext{
7 Confucian Myth, edited by Ye Shuxian, Tang Qicui, (Guangzhou: Nanfang Daily Press, 2011), 63-64.

${ }^{8}$ For more information, see the preface of Confucian Myth, Edited by Ye Shuxian, Tang Qicui, (Guangzhou: Nanfang Daily Press, 2011), 9. Also see Ye Shuxian, Tang Qicui, On Confucian Myth, Social Science Front, 9(2011), 126-134.

${ }_{9}$ For more information, see Robert Redfield, Peasant Society and Culture: an Anthropological Approach to Civilization (the University of Chicago Press, 1956), 70. He comments the two concepts as: This pair of phrases is here chosen from among others, including "high culture" and "low culture," "folk and classic cultures," or "popular and learned traditions.” I shall also use "hierarchic and lay culture."
} 
character coding as the little tradition, and that of the pre-text period as the great tradition. There is an easily identifiable mark to distinguish them which is the presence or absence of the character system." ${ }^{10}$ And he argues again in An Introduction to Literary Anthropology: "written texts neither occupy the primary position, nor enjoy the privileges of the literary domination. Written history for three or four thousand years, only relatively restoring it to the end of cultural history of 100,000 years-old oral tradition to understand, should not yet be a hotbed of breeding text priority." 11 Apparently, the simple change of the great tradition and the little tradition gives us profound enlightenment and can be used as an effective tool for Chinese literary anthropology, especially when entering the Confucian myth.

Since two thousand years ago, Confucian scholars, who lived in the little tradition, inevitably trapped into the written texts when they studied the Confucian classics all of their lives. Likewise, they didn't have the ability to go beyond the written tradition, and could not thoroughly understand the cultural essence in pre-written times. It is very typical in Chinese classical studies that Confucian scholars focus more on explaining the words and sentences in the Confucian classical texts according to philosophical connotations and text structure, and attempt to simply explore the cultural tradition by literature analysis. The differences between the great tradition and the little tradition will remind us, when entering Confucian tradition, not to be eclipsed by the little tradition, but to do well in grasping the writing in the actual context outside of the written text. Zilu 子路 (a.542-480BCE), a student of Confucius, has already said: "Learning consists in other things besides reading books” 何必读书, 然后为学. These words, quoted from The Analects, also seem to warn the late researchers not to merely concentrate on the written texts, and to pay more attention to the great tradition in pre-written times. After analyzing the written history of major civilizations in the world in his essay The Analects of Confucius and the Oral Tradition, Ye Shuxian proposes that there was a profound oral tradition at least lasting more than 100,000 years, while the character was only invented about 5,000 years ago (in China, only more than 3,000 years ago). Although oral tradition as a whole has gradually been replaced by written culture, the far-reaching influences, due to twenty times longer than written tradition, will not immediately stop. There was quite a long transitional phase in early civilization-that is to say, the coexisting of both the communicational and educational ways of oral culture and written culture. Until the writing tool and condition technically attain the considerable social penetration, the information exchange pattern of oral culture will be probably replaced by written culture. Relating to the transmission from oral tradition to written tradition, he re-evaluates Confucius: "Although Confucius is regarded as the great saint by the written culture, but, in fact, his real identity is closer to the last saint of oral tradition. In other words, Confucius is the old-fashioned traditionalist who still fully retains the oral cultural values when the era of written culture comes in. especially, the value system, with his extreme preference to the communicational pattern of oral culture such as music and poetry, etc. leads to his political ideal to restoring to the ritual system of Western Zhou Dynasty (1046-771BCE). The past research of Confucianism basically ignored the value elements of oral cultural origin because they laid excessive emphasis on Confucius thoughts in politics and history. "12 The selections quoted here thoroughly display that Confucius inherited oral culture of Chinese civilization, and also criticize the past scholars who ignore oral cultural origin and misread Confucian thoughts. He repeatedly suggests us that The

\footnotetext{
${ }^{10}$ Ye Shuxian, Great Tradition and Little Tradition of Chinese Culture, Journal of Party Building, 7 (2010), 49.

11 Ye Shuxian, An Introduction to Literary Anthropology, (Beijing: Chinese Social Science Press), 99.

12 Ye Shuxian, Confucius Analects and Oral Cultural Tradition, Journal of Lanzhou University, 2 (2006), 2.
} 
Analects, which being viewed as Confucian bible, factually is not written by Confucius, but the "living fossil" of traditional education with oral communication. Therefore, we cannot rely solely on the written text of Confucius, but rather focus on its profound value elements of oral culture.

Thus, we should pay special attention to oral tradition in which "Confucian myth" is produced; we would not fully grasp the significance which is often concealed by written texts. In order to make the reader properly understand the mother-children relationship between great tradition and little tradition, Ye Shuxian outlines the following formulas in the essay Examination of Chinese Saint Archetype:

Literature $=$ Little tradition of written culture $=$ Signifier

Quadruple evidence $=$ Great tradition behind the literature $=$ Signified

He also "lays much emphasis upon the technique of interpreting quadruple evidences, which is the new method to go back to the deeper tradition." ${ }^{, 13}$ In Chapter 3 of Confucian Myth, I Heard Them with Docile Ear at Sixty: the Metaphor of the Sanctification 六十耳顺: 成圣的隐喻, he makes full use of the intellectual context of oral culture to analyze the hidden myth in Confucianism. Ye frequently suggests: "What needs searching is the real context of a given oral culture which is difficult to understand for the later generations... Owing to the long history of accumulation during the unwritten period, the transmitting mode of knowledge and experience of oral education for hundreds of thousands of years has long been overlooked. Undoubtedly, the hearing organ is the primary organ through which the ancient people receive information... The concept of body and learning in oral culture, constitutes the long tradition before the emergence of written text. For instance, the problem of hearing memory of information exchange and thought stimulation by mouth and ear and the epistemological sense of auditory perception represented by the ear, are not easy to comprehend for later generations if not restored to oral culture... In oral tradition, the standard of the saints will not be literal, but superior hearing capability of comprehension and memory of oral context." ${ }^{, 14}$ We list these discourses to prove that, if we neglect the sacred context of great tradition, we cannot thoroughly understand the Confucian myth.

Of course, Ye Shuxian's emphasis on oral tradition will make us wonder: Though Confucianism and Taoism both come from the great tradition, there is no literal record in oral culture. Then, what is the symbolic indicator of the living myth and belief of the primal inhabitants? Recently, based on his research on prehistoric culture, he has discovered that there is a latent and unique prehistoric belief in the divinity of jade, that is, a jade religion in early Chinese civilization. The original jade religion can be traced back to northern culture of Xinglongwa 兴隆洼文化 about eight thousand years ago, then continues from the cultures of Hongshan 红山 文化, Xiaoheyan 小河沿文化, Longshan 龙山文化 to Erlitou 二里头文化, and the southern cultures of Liangzhu 良渚文化, Shijiahe 石家河文化 and western Culture of Qijia 齐家文化 absorbed, and evolved into Shang and Zhou Dynasty ceremonial music institution, and eventually became the Confucian Junzi 君子 ideal tradition of “good moralities as jade” 比德于玉 and the Taoist seeking immortal belief of “eating jade for eternal life” 食玉永生. The mythical tradition of jade, which was the common origin of Confucianism and

\footnotetext{
${ }^{13}$ Confucian Myth, edited by Ye Shuxian, Tang Qicui, (Guangzhou: Nanfang Daily Press, 2011), 74. For more information, also see his essay, New Examination of mythical archetype of Chinese Saint, Wuhan University Journal, 3(2010), 277-286.

${ }_{14}$ For more information, see "I Heard Them with Docile Ear at Sixty: the Metaphor of the Sanctification", in Confucian Myth, Edited by Ye Shuxian, Tang Qicui, (Guangzhou: Nanfang Daily Press, 2011), 83-88.
} 
Taoism, belongs to the great tradition. ${ }^{15}$ Prehistoric sacred objects and symbolic belief-jade religion, which is discovered by Ye Shuxian, is a significant path to enter the great tradition, and also is an important clue to interpret the Confucian saint system. He argues in Confucian Myth: "We clearly realize, by means of the unearthed jade, that the great tradition of divine jade is much deeper than the written tradition... Chinese mythic concept will be unusually meaningful if we don't rigidly adhere to the concept of gods. With the concept of holy and the special symbolic clue of jade ware, the lost tradition behind the Confucianism will be reinvented...jade, a holy thing, which is naturally and uniquely transmitted in Chinese culture, undoubtedly, is a special character and a meaningful symbol."16

The recognition of the importance of the sacred object of jade religion, as well as emphasis on its great transformation from oral tradition to written tradition, will methodologically provide new evidence for reinterpreting Confucian myth. If we merely focus on the written texts and deviate from the concrete context which originally determines the meaning of oral discourses, then the explanation of traditional culture will be fully subjective.

\section{Mythical Archetype of Cultural Text}

In the three decades, Ye Shuxian has continually reflected on the cultural criticism of local context and strived to explore the effective way to integrate the Occidental and Oriental academic patterns. He puts in The Footprints of Two Kinds of Travel: "The understanding of the long history of local culture is lack in the cross-cultural perspective; if we adopt the comparative method, it will be easy to understand what is traditionally unable to resolve... I suggest, for reconstructing the theoretical discourses, that native discourses can be translated, interacted and interpreted in light of foreign discourses." He argues that "cross-cultural comparison" is the effective way to go out of traditional text-centrism. At the same time, he attempts to establish the basic principle which enables us to communicate internal culture with external culture. Thus, when he and his colleagues choose some Chinese classics such as Shijing 诗经, Chuci, Laozi, Zhuangzi and Shuowen jiezi 说文解字 to practice the cross-cultural interpretation, they “expect to transfer the micro-textual critical pattern of Qianjia School 乾嘉学派 in Qing Dynasty (1664-1911) to the cross-cultural interpretational paradigm.” ${ }^{17}$ The process is long-term, hard and not straight forward, but the results have been gradually advancing and greatly fruitful. Especially in methodology, he successively brings up "triple evidence" and "quadruple evidence" to show that there is a wide gap to bridge between Chinese literary anthropology and cross-cultural studies.

\footnotetext{
${ }^{15}$ For more information, see the series of essays about jade religion written by Ye Shuxian: Construction of the Belief of Eating Jade and Western Myth, Journal of Seek Roots, 4 (2008); The Narrative of Jade, Chinese Social Science Newspaper, July 1, 2009; The Jade Religion and Mythical Origin of Ideas of Confucianism and Taoism, Ethnic Arts Quarterly, 3 (2010); New Examination of Mythical Archetype of Chinese Saint, Wuhan University Journal, 3 (2010); Nüwa Repairs the Sky and the Mythic Concept of the Sky Made by the Jade, Ethnic Arts Quarterly, 1 (2011); International Perspective of Jade Ware Period and the Original Research of Civilization, Ethnic Arts Quarterly, 2 (2011).

${ }^{16}$ Confucian Myth, Edited by Ye Shuxian, Tang Qicui, (Guangzhou: Nanfang Daily Press, 2011), 65-68.

17 Ye Shuxian, The Footprints of Two Kinds of Travel, (Shanghai: Shanghai Literature and Art Press, 2000)144-146. For more information, see Ye Shuxian, "Methodology", the forth part of an Introduction to Literary Anthropology (Beijing: Chinese social science Press, 2010), 343-366.
} 
The following chart made by Ye Shuxian illustrates the "quadruple evidences" and the "five kinds of narratives". ${ }^{18}$

\begin{tabular}{|l|l|l|}
\hline Classification of Method & Material Scope & Classification of Narrative \\
\hline Single evidence & Written document & Literal narrative \\
\hline Duel evidence & Unearthed written document & Literal narrative \\
\hline Triple evidence & $\begin{array}{l}\text { Living oral material and cross-cultural } \\
\text { anthropological material }\end{array}$ & $\begin{array}{l}\text { Oral narrative } \\
\text { Ritual narrative }\end{array}$ \\
\hline Quadruple evidence & Unearthed and written objects and pictures & $\begin{array}{l}\text { Graphic narrative } \\
\text { Object narrative }\end{array}$ \\
\hline
\end{tabular}

The "quadruple evidences" should be approached from its profound structure and theoretical essence instead of being regarded merely as the superposition of many materials. We think that the rise of "quadruple evidence" marks that mythical archetype criticism has new progress in local cultural context. In the late of 1980s, he started to introduce Northrop Frye's archetypal criticism the mode and scope of which are fundamentally confined within the realm of literature. He reevaluates literary archetype in Meeting the paradigmatic Shift of Mythology: "We no longer simply focus on the archetype of the literary sense like that in the 1980s, but explore the cultural archetype outside the traditional paradigm of Frye, Mao Dun and Yuan Ke 袁珂 (1916-2001). We are going to trace the cultural archetypes represented by pictures and things, which are more abundant than those represented by written text. By means of creating some new knowledge with graphic narrative and object narrative, we will redefine the boundary of literary narrative. Thus it will be enough to go beyond the disciplinary boundary among literature, history and philosophy, especially with the help of the mythical pictures and objects which are continually unearthed by archaeologists, we would probably find out the mythical archetype of cultural gene.” ${ }^{, 19}$ In this paragraph, he argues that Frye’s literary archetype, which is the product of the written culture, is so narrow that it seriously impedes the academic development. Only through the great tradition can we probably explore the real cultural gene. We can see that, on the one hand, the postmodern concept of myth prompts him to reinvent the literary archetype, and on the other hand, the wisdom of great tradition helps him to complete the paradigmatic shift-from literary archetype to cultural archetype. And these shifts, from "single evidence" to "triple evidence", in other words, from literary text to oral text, are undoubtedly the result of the symbolic ages. However, we should ask whether there is a non-linguistic and non-literary period, namely the period of pictures and objects before language emerges. Do the pictures and objects produced by the primitive inhabitants have cultural function and aesthetic implication? Are they the so-called pure arts? We argue that instead of being purely decorative and aesthetic, they constitute a type of silent symbols which has profound cultural significance and transmits the particular beliefs and values of the

\footnotetext{
${ }^{18}$ For more information, see the documents as follows to quadruple evidence: Quadruple Evidence: Vision Persuasion of Comparative Iconology, Literary Review, 5 (2006); Erlitou 二里头 Bronze Medal and Xia Dynasty Mythic Research, Ethnic Arts Quarterly, 4 (2008); General Explanation of the Myth about Gun 鲧, Yu禹, Qi 啓 Changing into Bear 化熊, International Conference Proceedings of Literature and Myth, (Taibei: Taiwan Zhong Xing University,2008); Xuan Yuan 轩辕 and the Bear 有熊, Journal of Guangxi University for nationalities, 5 (2008); “Rongchengshi” Xia Yu Jian Gu《容成氏》夏禹建鼓, Ethnic Arts Quarterly, 1 (2009); Exploring Iconological Origin of Xuanniao’s 玄鸟 Archetype, Ethnic Arts Quarterly, 3 (2009); Lawful Research of Evidence and Forecast of Textual Critical of National Culture, Journal of Evidence Science, 4 (2009); New Examination of Mythical prototype of Chinese Saint, Wuhan University Journal, 3 (2010); An Introduction to Literary Anthropology, (Beijing: Chinese Social Science Press, 2010.

19 Ye Shuxian, Meeting the Paradigm Shift of Mythology, Ethnic Arts Quarterly, 3 (2009), 25-26.
} 
prehistoric inhabitants.

We point out that the art image or literary archetype, which is created by the writing, is the transformation of cultural coding hidden in the pictures and objects. If we simply take them as natural objects or objective phenomena, undoubtedly, we will lose the ideographic system produced by the archaic peoples. At the same time, if the "quadruple evidence" is regarded as the mythical archetype, we will gain new insight to surpass the written archetype, and releasing more energy to enter the origin of Chinese civilization, we will be freed from the superficiality and misunderstanding caused by the literary archetype. He writes in the preface to Goddess with a Thousand Faces: "The so-called comparative iconology, which can be viewed as archetypal iconology, strives to grasp the basic archetype, to thoroughly investigate the origin and evolution of the goddess image in different cultures, to realize the mainstream to overcome the short sight which only see the part but not the whole, to keep an eye on global system."20 Obviously, we realize that the transformation from "triple evidence" to "quadruple evidence" is a substantially big leap from literary archetype to cultural archetype. It also shows that Chinese literary anthropology apparently attains the significant breakthrough by methodologically reconstructing the "cross-cultural interpretation". He exhaustively defines the concept and function of quadruple evidence in The Quadruple Evidence: Visional Persuasion of Comparative Iconology:

"Besides the limited unearthed materials, I hope to seek enough evidences to provide an opportunity for self-reconstructing the basic knowledge of textual criticism, and to apply the local methodology to obtain the cultural characteristics though dialogue and interaction with Western culture. So I will especially regard material culture and graphic documents as quadruple evidence of humanities." ${ }^{21}$ We think that his "quadruple evidence" and cultural text of mythical archetype are greatly related to the "concept of culture" and "the interpretation of culture" as suggested by Clifford Geertz. These are possible through the integration of many disciplines such as cultural anthropology, phenomenology and comparative mythology and so on. We also realize that cultural transformation of mythical archetype is synchronized post-modern concept of myth with sacred context of great tradition. So they are the concrete demonstrations of the new turn of Chinese literary anthropology at the beginning of the 21st century.

Certainly, prehistoric pictures and objects cannot be entirely separated from the historical texts; otherwise their tremendous potential will not be demonstrated to the full. Therefore, Ye Shuxian insistently highlights the significance of "quadruple evidence" on the one hand, and on the other hand, he also suggests that we should comprehensively apply the various evidences, of which "quadruple evidence" proves the most effective, to achieve the recognition of cultural integration and to obtain the new pattern of three-dimensional interpretation. Just as he points out, we "try to explore the quadruple evidences, and want to amend the three-dimensional representation and multi-dimensional interpretation to go beyond the debates between Doubting Antiquity 疑 古 and Interpreting Antiquity 释古 in modern Chinese context. Specifically, we need integrate four kinds of evidences: literature text in the history, unearthed Silk or Bamboo text, the field investigation of ethnography and the interpretation of the unearthed materials, so the silent objects will have a narrative function and can extremely expand the new insights into the history of culture." 22 With this new perspective we believe that Confucian myth is not only the product of linguistic symbol period—but also the product of transitional period

${ }^{20}$ Ye Shuxian, Goddess with a Thousand Faces, (Shanghai: Shanghai Academy of Social Sciences Press, 2004), 1.

21 Ye Shuxian, the Quadruple Evidence: Visional Persuasion of Comparative Iconology, Literature Review, 5 (2006), 173.

22 Ye Shuxian, the Comparative Mythological Perspective of Exploring Origin of Civilization, Journal of Jiangxi Social Science, 6 (2009), 20. 
from oral culture to written culture. So it is a mediator which mingles prehistoric tradition with post-historic tradition, and also is the system of belief and idea which evolves from prehistoric graphic archetype. So if we are confined to literary archetype, it will be dangerous for the academic due to limit of linguistic symbol, and also will cause cultural misreading and sheltering. Therefore, from the single literary archetype to organic integration of cultural archetype with literary archetype, the archetypal transformation gradually makes us understand the essence of Confucianism. In this process, we can not only catch the archetypal coding of Chinese culture, but also compare the evolution of various kinds of cultural archetype during the prehistoric period and post-historic period.

Ye Shuxian, eagerly informing his readers of the essence of cultural archetype, often discusses "quadruple evidence" and "three-dimensional interpretation of the antiquity" in his academic works and epeeches. He argues recently in Confucian Myth: "How to link the modern comparative mythology with anthropological knowledge to establish the quadruple evidences and to apply them to the three-dimensional interpretational paradigm of cultural integration, which will promote the development of archaeological materials and methods, is the most urgent task... How to transform the research paradigm from mythical research of pure literature to cultural integration of quadruple evidences and five kinds of narratives, with the help of anthropological perspective, is the new opportunity for contemporary scholars to go beyond the 'Doubling Antiquity' School 疑古学派 and to renew the way to enter the history of religion and civilization." ${ }^{23}$ Owing to the perspective of material culture, he naturally finds out the prehistoric great tradition — jade religion. He proposes that jade is the most sacred thing in Chinese civilization. The primal inhabitants combine jade with various types of sacred animals and plants which have special values and beliefs, to form a complex holy genealogy. Thus the special values and beliefs will be transformed into the sacred images of the written text. By relating material culture to mythical image, which can provide kinds of clues to enter prehistoric civilization, we will really experience the being of Confucian. For example, he makes use of the unearthed materials as "quadruple evidence" and oral materials as "triple evidence" to draw the outline of the sacred jade bell belief and its post-historic formal evolution. The practice of cultural interpretation fully proves the effectiveness and rationality of cultural archetype.

In conclusion, it is of great methodological significance that Ye Shuxian transforms literary archetypal criticism to cultural archetypal criticism in Chinese local context. From perspective of the time, the cultural archetypal criticism turns culture from written to material. In terms of the symbolic values, it restores symbolic coding of speechless period from literary archetype which is changed by the linguistic symbol. From the perspective of evident effect, the archetypal values of primitive visual images go beyond that of the reconstructed symbolic archetype. In terms of the generating origin of human civilization, the material archetype can show the original source of primal religious rituals. The presence of "quadruple evidence" and the turn to cultural archetype will transform the cross-cultural paradigm, and will eventually be an effective tool in understanding the Confucian myth.

\section{References}

Ye Shuxian. (2009). Meeting the Paradigm Shift of Mythology. Ethnic Arts Quarterly, 3, 20.

\footnotetext{
${ }^{23}$ Confucian Myth, Edited by Ye Shuxian, Tang Qicui, (Guangzhou: Nanfang Daily Press, 2011), 59-75.
} 
Ye Shuxian. (2011). Myth: Archetype Code of Chinese Culture. In Tang Qicui, Ritual Institutional Civilization and Mythical Code (p. 2). Guangzhou: Nanfang Daily Press.

Ye Shuxian. (2007). Post-modern Concept of Myth. Chinese Comparative Literature, 1.

Ye Shuxian, Tang Qicui. (Eds.). (2011). Confucian Myth. Guangzhou: Nanfang Daily Press.

Robert Redfield. (1956). Peasant Society and Culture: an Anthropological Approach to Civilization. The University of Chicago Press.

Ye Shuxian. (2010). Great Tradition and Little Tradition of Chinese Culture, Journal of Party Building, 7.

Ye Shuxian. (2010). An Introduction to Literary Anthropology. Beijing: Chinese Social Science Press.

Ye Shuxian. (2006). Confucius Analects and Oral Cultural Tradition. Journal of Lanzhou University, 2.

Ye Shuxian. (2000). The Footprints of Two Kinds of Travel. Shanghai: Shanghai Literature and Art Press.

Ye Shuxian. (2006). Quadruple Evidence: Vision Persuasion of Comparative Iconology. Literary Review, 5.

Ye Shuxian, Erlitou 二里头. (2008). Bronze Medal and Xia Dynasty Mythic Research, Ethnic Arts Quarterly, 4.

Ye Shuxian. (2008). General Explanation of the Myth about Gun 鲧, Yu 禹, Qi 啓 Changing into Bear 化熊. International Conference Proceedings of Literature and Myth. Taibei: Taiwan Zhong Xing University.

Ye Shuxian. (2008). Xuan Yuan 轩辕 and the Bear 有熊, Journal of Guangxi University for nationalities, 5.

Ye Shuxian. (2009). “Rongchengshi” Xia Yu Jian Gu《容成氏》夏禹建鼓, Ethnic Arts Quarterly, 1.

Ye Shuxian. (2004). Goddess with a Thousand Faces. Shanghai: Shanghai Academy of Social Sciences Press.

Ye Shuxian. (2006). The Quadruple Evidence: Visional Persuasion of Comparative Iconology, Literature Review, 5.

Ye Shuxian. (2009). The Comparative Mythological Perspective of Exploring Origin of Civilization, Journal of Jiangxi Social Science, 6. 